Original Research Paper

\title{
Evaluation of Polymorphisms at Heat Shock Protein 90 Gene by High Resolution Melting Assays for Potential Heat Tolerance among Nigerian Zebu Cattle Breeds
}

\author{
${ }^{1,3,4,6}$ Gbolabo Onasanya, ${ }^{2,3}$ George Msalya, ${ }^{3}$ Aranganoor Thiruvenkadan, ${ }^{4}$ Chirukandoth Sreekumar, \\ ${ }^{5}$ Krishnaswamy Tirumurugaan, ${ }^{6}$ Sanni Muyideen, ${ }^{7}$ John Decampos, ${ }^{8}$ Ayotunde Amusan, ${ }^{6}$ Olajide \\ Olowofeso, ${ }^{9}$ Adeboye Fafiolu, ${ }^{10}$ Moses Okpeku, ${ }^{11}$ Abdulmojeed Yakubu and ${ }^{6}$ Christian Ikeobi \\ ${ }^{1}$ Department of Animal Science, Federal University Dutse, Dutse, Nigeria \\ ${ }^{2}$ Department of Animal, Aquaculture and Range Sciences, Sokoine University of Agriculture, Morogoro, Tanzania \\ ${ }^{3}$ Mecheri Sheep Research Station Pottaneri, Tamil Nadu Veterinary and Animal Sciences University, Chennai, India \\ ${ }^{4}$ Biotechnology Center, Postgraduate Research Institute in Animal Sciences, Kattupakkum, Tamil Nadu Veterinary and Animal \\ Sciences University, Chennai, India \\ ${ }^{5}$ Department of Animal Biotechnology, Madras Veterinary College, Tamil Nadu Veterinary and Animal Sciences University, \\ Chennai, India \\ ${ }^{6}$ Deparment of Animal Breeding and Genetics, Federal University of Agriculture, Abeokuta, Nigeria \\ ${ }^{7}$ Department of Animal Production, University of Ilorin, Kwara State, Nigeria \\ ${ }^{8}$ Department of Animal production, Federal College of Agriculture, Moor Plantation, Ibadan, Nigeria \\ ${ }^{9}$ Department of Animal Nutrition, Federal University of Agriculture, Abeokuta, Ogun State, Nigeria \\ ${ }^{10}$ Department of Genetics, School of Life Sciences, University of KwaZulu-Natal, Westvile Campus, Durban, South Africa \\ ${ }^{11}$ Department of Animal Science, Faculty of Agriculture, Nasarawa State University, Keffi, Shabu-Lafia Campus, Lafia, Nigeria
}

Article history

Received: 15-12-2019

Revised: $13-01-2020$

Accepted: 02-03-2020

Corresponding Author: George Msalya

Department of Animal,

Aquaculture and Range

Sciences, Sokoine University

of Agriculture, Morogoro,

Tanzania

Tel: +255 $232603511-14$

Email: msalya@sua.ac.tz
Abstract: Heat Shock Protein (HSP) 90 gene is a member of HSPs subfamily that act as molecular chaperons whenever animals come under thermal stress. The genes fulfill essential roles of providing cellular protection, immune response, protein synthesis, protein folding and unfolding, protection from cellular stress, inhibitory apoptosis and adaptation. This study was designed to analyze polymorphisms of HSP 90 and to evaluate their influence on heat tolerance among selected Nigerian zebu. The polymorphisms were also used to determine genetic relationship among the animals. About 450 bp of bovine HSP 90 including part of coding region in exon 3 was sequenced in 90 DNA samples representing four Nigerian zebu namely White Fulani (WF), Sokoto Gudali (SG), Red Bororo (RB) and Ambala (AM). Sequencing was done using an automated ABI-DNA Sequencer. Editing was accomplished using chromatogram analyses on SeqMan Ngen Tool. Rooted phylogenetic tree was constructed using MEGA 5.2 software. In total, 11 genetic variants were determined. Five of these (PRP, RED, ORG, LMN and YLO) were major variants detected in over $70 \%$ of the samples. Six (6) were classified as minor variants detected in two breeds or less and in $29.1 \%$ of the samples. The GRN and NBL were only detected in RB and SG breeds respectively. We found a shared homology and common ancestral lineage among the breeds. Furthermore, the genetic structure of Nigerian zebu has a common clade architecture to those of goats, sheep, yak, buffalo, camel, horse and other taurines. The gene is conserved among wide range of animals and as such it can serve as one of bio-markers for selection and breeding programmes for thermotolerance in wide range of livestock animals under thermal stress. The variant groups could be further interrogated for possible specific effects on thermotolerance performance of zebu in hot tropical environments.

Keywords: Bio-marker, Bos indicus, Genetic Variants, Phylogeny, Thermal Assault

(C) 2020 Gbolabo Onasanya, George Msalya, Aranganoor Thiruvenkadan, Chirukandoth Sreekumar, Krishnaswamy Tirumurugaan, Sanni Muyideen, John Decampos, Ayotunde Amusan, Olajide Olowofeso, Adeboye Fafiolu, Moses Okpeku, Abdulmojeed Yakubu and Christian Ikeobi. This open access article is distributed under a Creative Commons Attribution 


\section{Introduction}

The concern of Heat Stress (HS) has increased in recent years with the realisation of influence of global warming on the environment and subsequently on animal production (West, 2003). The HS has become a major issue in the era of climate change and it directly affects adaptability and survivability of livestock to thermal assault (Onasanya et al., 2019). It has been shown that animals can succumb to hyperthermia when they fail to abate the impact of HS load (Onasanya et al., 2019). The impact of HS must be ameliorated to maintain animal health status, adaptability, survivability and performance. Compared to caprine and ovis, bovines have lesser tolerance to HS and therefore understanding ways of solving this challenge is of great importance in the management of the latter group of animals (Kapila et al., 2013). Increased HS in cattle and other bovine species in general has been linked to poor food intake and slow metabolism, thereby affecting growth, milk production and reproductive efficiency, consequently leading to economic loss. Several management strategies have helped to lower the stress in dairy and beef animals but to a limited extent (Kapila et al., 2013). Among the bovine, Bos (B.) taurus cattle and buffalos (Bubalus bubalis) have been reported to be affected more compared to Bos $(B$.) indicus. A study conducted by Hansen (2004) showed that zebu cattle were superior in adapting to the tropical climatic conditions compared to cattle introduced from the temperate countries. In different places including India, the zebu cattle have been reported to be naturally adapted to different hot agro-climatic conditions (Kapila et al., 2013; Sodhi et al., 2013b). It is believed that better heat tolerance in zebu breeds could be due to their emergence and natural selection through generations.

The Heat Shock Protein (HSP) genes including HSP 70 and HSP 90 are members of HSPs sub-family (molecular chaperone families) known to be highly expressed under stressful environmental and physiological conditions. These facilitate responses to environmental heat loads above thermo-neutral zones in animals through intra and extracellular signals that coordinate cellular and whole animal metabolism (Collier et al., 2008). Also, the genes regulate cellular homeostasis and folding-unfolding of damaged proteins during thermal assault thereby conferring on stressed animals the adaptive capacity to cope under stressful environmental conditions (Kapila et al., 2013). Through overexpression during HS, the HSP genes provide a mechanism for protecting the animal against hyperthermia, circulatory shock and cerebralischemia (Lee et al., 2006; Collier et al., 2008). In particular, the HSP 90 gene is essential for providing cellular protection (cyto-protection), immune response, protein synthesis, cyto-skeletal protection, protein translocation and regulation of steroid hormone receptors, transportation, re-folding of protein, protection proteins from cellular stress, inhibitory apoptosis and adaptation during and after thermal assault (Kapila et al., 2013; Sodhi et al., 2013b). The bovine HSP genes have been extensively studied in various cattle breeds. For example, single nucleotide polymorphisms (SNPs) were identified in HSP 70.1 locus and were linked to diseases susceptibility or HS tolerance in B. taurus cattle (Basiricò et al., 2011). The HSP 90 gene has been shown to provide genomic basis for thermo-tolerance selection among tropical animals under thermal assaults. Similarly, a novel SNP in the ATP1A1 gene was associated with heat tolerance traits in dairy cows (Li et al., 2011).

Nigeria is a tropical country with severe influence of thermal stress that significantly affects production performance of livestock including cattle. According to Pagot (1992) and Babayemi et al. (2014), the most prominent autochthonous breeds of cattle in Nigeria include White Fulani (WF), Sokoto Gudali (SG), Adamawa Gudali (AG), Red Bororo (RB), Ambala (AM), Wadara (WA), Azawak (AZ), Muturu (MU), Keteku (KE), N'Dama (ND) and Kuri (KU). The WF Fulani cattle breed also known as Bunaji is the most widely spread local breed and most numerous comprising 37\% of all cattle (Meghen et al., 1999; NNLRS, 1999; Alphonsus et al., 2012). Furthermore, they are valued for their genetic predisposition of hardiness and are superior to other breeds in terms of diseases resistance, heat tolerance, ability to thrive under varying thermal environment and adaptation to other local conditions (Blench et al., 1998; Alphonsus et al., 2012). Regarding phenotypic characteristics of WF, the hump is large and well developed, navel flap is small, horns are of medium length, up curving and lyre shaped. With respect to socio-economic importance, these are kept for beef and milk production as well for draft power (Kubkomawa, 2017). The SG and AG are two distinct strains of the major group of Gudali animals estimated to form $32 \%$ of the national cattle herd (NNLRS, 1999). The SG also known as Bokolooji (in local language) are predominantly found in the north-western part of the country particularly in Sokoto and are mainly dual purpose animals. The RB (Rahaji) is another prominent $B$. indicus cattle breed and constitute $22 \%$ of total herd. The RB animals are larger zebu distinguished by deep burgundy/red-colour coat, pendulous ears and long-thick horns (Katie and Alistair, 1986; Williamson and Payne, 1990). The RB cattle are adapted to arid and semi-arid regions, however they cannot tolerate humidity-related disease and poor nutrition (Blench et al., 1998; Kubkomawa, 2017). These animals are rarely found beyond Kaduna in North-Central in the wet season except for the isolated population on Mambila Plateau in the North-East of Nigeria (Meghen et al., 1999).

In Nigeria, no feasible effort has been made to study the $H S P$ genes in livestock especially cattle for possible 
characterization of these candidate genes. Therefore, the goal of this study was to pioneer the evaluation of HSP genes for possible detection of polymorphisms and evaluation of genetic diversity in four selected Nigerian zebu cattle breeds. Our long-term interest is to establish scientific evidence for tolerance of these animals to HS, a valuable trait speculated by farmers in the country. We chose to analyze polymorphisms and quantify the HSP 90 gene in four local zebu breeds (WF, SG, RB and AM) to provide scientific basis for future selection among these animals. Furthermore, detection of genetic variants of HSP 90 was used in the determination of genetic relationships among the animals. Moreover, results of the present study are intended to provide important information for developing future management and efficient resource utilization programmes for local cattle of Nigeria and elsewhere in the face of climate change, thereby leading to improved performance of various traits such fertility, milk production, feed intake, growth, conception rates and animal health.

\section{Materials and Methods}

\section{Study Animals and Sampling Regions}

Four distinct local zebu cattle breeds of Nigeria namely WF, SG, RB and AM (Fig. 1) were involved in this study.

Map of Nigeria showing northern parts of the country where random sampling was done (Fig. 2). Commonly in
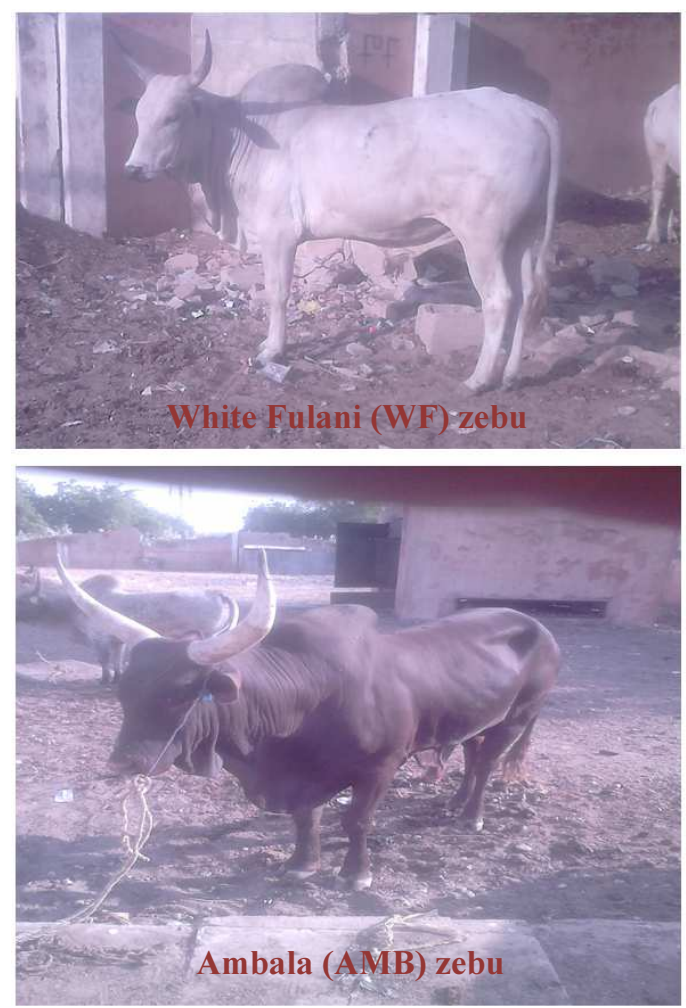

northern Nigeria, the animals are found in traditional herds and are reared under the extensive system where mainly grazing in natural pastures is practiced. Department of Agriculture and Livestock granted permission to sample the animals. The natural pastures mainly comprise of Stylo (Stylosanthes gracilis), Leucaena (Leucaena leucocephala) and Guinea grass (Panicum maximum) as well as crop residues during harvesting.

Skin tissue samples were taken from 90 adult bulls representing the four breeds $(25 \mathrm{WF}, 21 \mathrm{SG}, 21 \mathrm{RB}$ and 23 AM) immediately after slaughter. The sampling was extended for 50 days and the age range of the animals was between 5 and 8 years. From each animal, about $200 \mathrm{~g}$ of skin tissue was excised from the abdominal region after bleeding. The skin sample was quickly sliced into $\leq 0.5 \mathrm{~cm}$ (or $1 \mathrm{~g}$ in weight) and submerged into $0.5 \mathrm{ml}$ Eppendorf tubes containing RNAlater. The tubes were packed in a dry iced-cool (about $4^{\circ} \mathrm{C}$ ) box during sampling and were transported (under same conditions) to the laboratory at the Federal University Dutse, Jigawa State for storage within sampling day (between 3 and 10 hours depending on distance). In the laboratory, samples were stored at $20^{\circ} \mathrm{C}$ for 2 to 3 weeks after which they were transferred to the Biotechnology Center, at Post Graduate Research Institute in Animal Science, Tamil Nadu University of Veterinary and Animal Sciences (TANUVAS) in Chennai, India where DNA extraction as well as all genomic analyses were conducted.
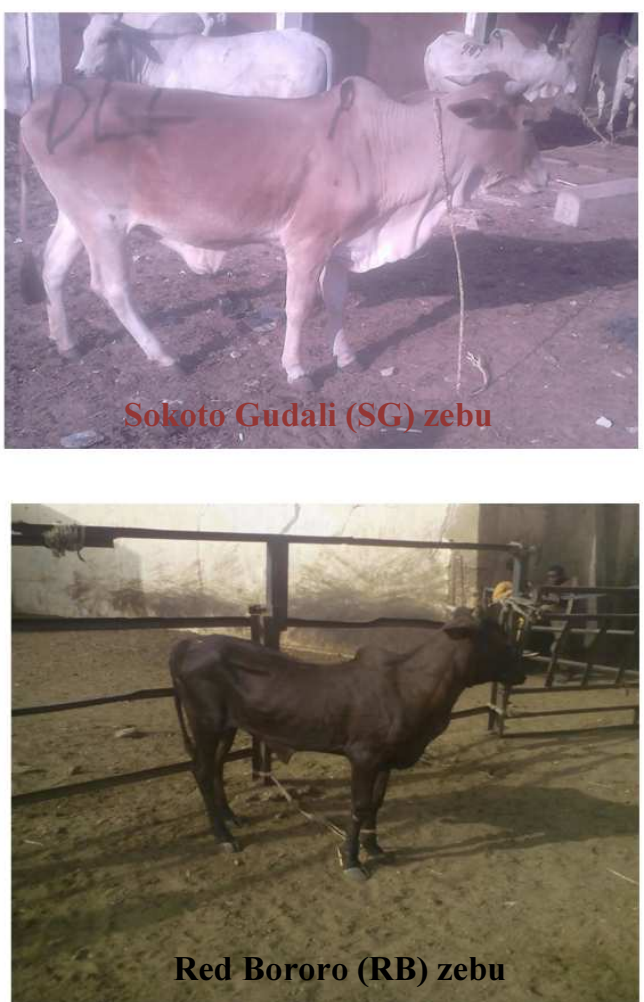

Fig. 1: Local Nigerian zebu cattle representing the four breeds involved in the present study 


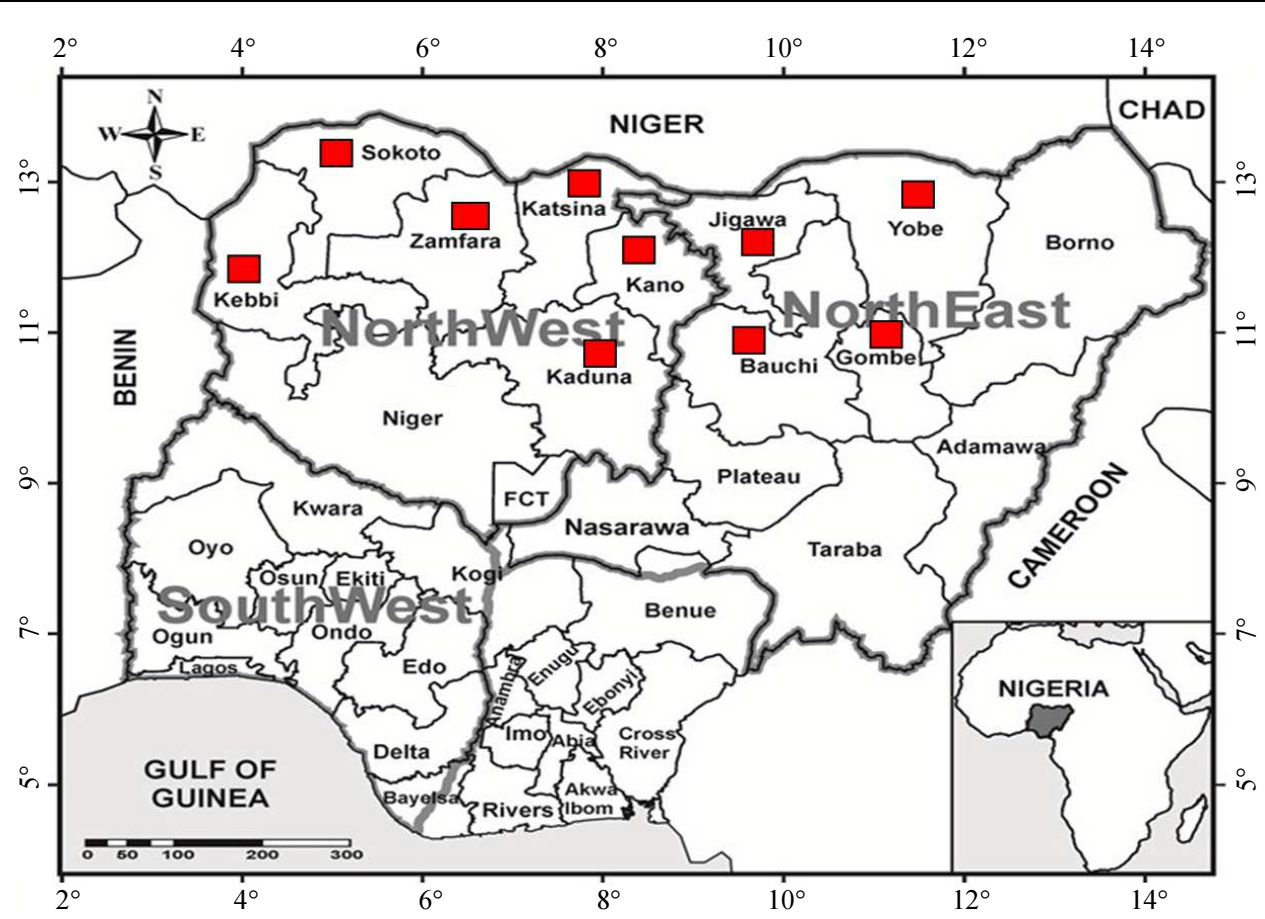

Fig. 2: Map of Nigeria showing the northern regions (red boxes) where sampling was done

\section{DNA Extraction}

The DNA was extracted from the skin tissue according to the procedure in HiPurA $^{\mathrm{TM}}$ Multi-Sample DNA Purification MolBio $^{\mathrm{TM}}$ Himedia ${ }^{\circledR}, \quad$ Mumbai, India). Briefly, from $1 \mathrm{~g}$ of skin tissue (skin samples) much smaller pieces (about $\sim 25 \mathrm{mg}$ ) were excised and transferred into 2 $\mathrm{mL}$ collection tube containing $180 \mathrm{uL}$ of re-suspension buffer $\left(\mathrm{MolBio}^{\mathrm{TM}}\right.$ Himedia ${ }^{\circledR}$, Mumbai, India) for digestion of the shredded skin tissue. Then, $20 \mathrm{uL}$ of proteinase $\mathrm{K}$ solution was added to the tissue, vortexed to mix thoroughly and allow proper digestion and incubated on ACCUBLOCK $^{\mathrm{TM}}$ digital dry bath (Labnet International, Edison, New Jersey, USA) at $55^{\circ} \mathrm{C}$ between 2 and $4 \mathrm{~h}$ until the samples were completely digested (with no residues). Within incubation period, the samples were intermittently vortexed for $30 \mathrm{sec}$ to further facilitate quick digestion. These steps were followed by addition $200 \mathrm{uL}$ of lysis solution to tube, vortexing for $15 \mathrm{sec}$ and re-incubation on ACCUBLOCK ${ }^{\mathrm{TM}}$ at $70^{\circ} \mathrm{C}$ for $10 \mathrm{~min}$ to generate lysate. The lysate was washed by $200 \mathrm{uL}$ of $100 \%$ ethanol, transferred into HiElute Miniprep spin column and centrifuged at $10000 \mathrm{rpm}$ for 1 minute using Thermo Scientific Nanofuge (MCROCL 21/21R) micro-centrifuge (Waltham, USA). The flow-through liquid was discarded and column was placed into a new $2 \mathrm{~mL}$ collection tube, adding $500 \mathrm{uL}$ of dilute pre-wash solution and was centrifuged at $10,000 \mathrm{rpm}$ for $1 \mathrm{~min}$. Then $500 \mathrm{uL}$ of diluted wash solution was added to the column with the lysate, centrifuged at 13,000 rpm for $3 \mathrm{~min}$, dried the column, spinning at $13,000 \mathrm{rpm}$ for $1 \mathrm{~min}$ and mixture (lysate) was transferred into new $2 \mathrm{~mL}$ collection tube. Elution buffer $(100 \mathrm{uL})$ was directly onto the column, incubating for $5 \mathrm{~min}$ at room temperature $\left(15-25^{\circ} \mathrm{C}\right)$ followed by centrifugation at $10,000 \mathrm{rpm}$ for 1 minute. Eluted DNA was incubated at $90^{\circ} \mathrm{C}$ to free the DNA from any contamination and was subsequently stored at $-20^{\circ} \mathrm{C}$ until analyses. The quality (DNA purity) and quantity of DNA was estimated using Thermo Scientific-Nano Drop 2000 Spectrophotometer (Shimadzu Co-operation, Kyoto, Japan) at absorbance ratio between $\mathrm{OD}_{260}$ and $\mathrm{OD}_{280}$ $\left(\mathrm{OD}_{260 / 280}\right)$. The DNA samples with absorbance ratio of 1.6-1.9 were considered sufficient for further analyses.

\section{Polymerase Chain Reaction, Sequencing and Construction of Phylogenetic Tree}

Polymerase Chain Reaction (PCR) was carried out in a final volume of $15 \mu \mathrm{L}$ containing $1.0 \mu \mathrm{L}$ of template DNA, 1.0 $\mu \mathrm{L}$ of each of forward and reverse primers, 7.5 $\mu \mathrm{L}$ of PCR Master Mix (2x) $\left(\mathrm{GeNei}^{\mathrm{TM}}\right.$ Red Dye PCR Master Mix, Bangalore, India) and $4.5 \mu \mathrm{L}$ of nuclease free water $\left(\mathrm{MolBio}^{\mathrm{TM}}\right.$ Himedia $\AA$, Mumbai, India). Primers targeting $450 \mathrm{bp}(826 \ldots 1276)$ including the coding region in exon 3 of bovine HSP 90 were obtained from a report published by Kumar et al. (2015) and are shown in Table 1. The primers were optimised for specificity to suit conditions of the current study. Amplification was performed in a TaKaRa Thermal Cycler Dice ${ }^{\mathrm{TM}}$ version III (Takara Bio Inc., Shiga, Japan) and involved 45 cycles of $94^{\circ} \mathrm{C}(60 \mathrm{sec})$ denaturation, annealing at $65^{\circ} \mathrm{C}$ for 45 seconds, extension at $72^{\circ} \mathrm{C}$ for $1 \mathrm{~min}$ and final extension 
at $72{ }^{\circ} \mathrm{C}$ for $7 \mathrm{~min}$. The initial heating of the DNA was done at $94^{\circ} \mathrm{C}$ for $5 \mathrm{~min}$. The PCR products were digested on $2 \%$ agarose gel electrophoresis after staining with 1 $\mathrm{ug} / \mathrm{mL}$ ethidium bromide and were visualised under BioRad Gel Doc ${ }^{\mathrm{TM}}$ XR+ Imaging System version 5.1 (Gel Documentation Molecular Imager, Bio-Rad Laboratories, Inc., California, USA). Subsequently, the PCR products were sequenced using an automated ABI DNA Sequencer (Eurofins Genomics Pvt. Ltd., Bangalore, India).

The nucleotide sequences were visualized and edited by chromatogram analyses on a SeqMan Ngen Tool (DNASTAR ${ }^{\circledR}$, Inc., Madison, Wisconsin, USA) and were used in evaluation of the degree of relatedness and ancestral evolution of the breeds (WF, SG, RB and AM) based on HSP 90 gene. To be able to do this, a rooted phylogenetic tree was constructed using MEGA 5.2 software according to Tamura et al. (2011). Then, the Nigerian animals were compared with selected mammalian species using nucleotide sequences obtained from GenBank (NCBI).

\section{Quantitative Real-Time PCR High Resolution Melting Analyses-Based Assay}

To carry out a quantitative real-time PCR (qRTPCR), $20 \mathrm{uL}$ of products obtained from thermocycler PCR (after electrophoresis on 2\% agarose gel and ethidium bromide staining) were carefully excised (particularly the DNA bands), placed into sterilised vials, then pestled and centrifuged for $5 \mathrm{~min}$ at $10,500 \mathrm{rpm}$. A layer of supernatant, the purified DNA was formed on the surface of the pestled gel. This was subsequently used as DNA template for qRT-PCR (high resolution melting, HRMA-based assays). The qRT-PCR was carried out on a final volume of $20 \mu \mathrm{L}$ containing $1.0 \mu \mathrm{L}$ of purified DNA fragment (template DNA), $1.0 \mu \mathrm{L}$ of each of the primers in Table $1,10.0 \mu \mathrm{L}$ of SYBR green Master Mix (2x) and 7.0 $\mu \mathrm{L}$ of nuclease free water. The amplification was performed in a Roche LightCycler ${ }^{\circledR} 96$ software version 1.01.01.0050 (Roche Diagnostics, Mannheim, Germany). The amplification condition consisted of pre-incubation for $5 \mathrm{~min}$, followed by 45 cycles of denaturation at $95^{\circ} \mathrm{C}$ for $10 \mathrm{sec}$, annealing at $65^{\circ} \mathrm{C}$ for 10 seconds and extension at $72^{\circ} \mathrm{C}$ for $10 \mathrm{sec}$. The first heating was $95^{\circ} \mathrm{C}$ for $60 \mathrm{sec}$ followed by cooling to $37^{\circ} \mathrm{C}$ for $30 \mathrm{sec}$, heating to $65^{\circ} \mathrm{C}$ for $1 \mathrm{sec}$ and then melting with continuous acquisition (15 readings $/{ }^{\circ} \mathrm{C}$ ) of florescence signal until $97^{\circ} \mathrm{C}$. The gene (HSP 90) was differentiated into distinct genetic variants via HRM curve profiles (derivative HRM curve/dissociation curve, differential plot and normalised melt curves) depicted with distinct SYBR green (dye) fluorescence depicting distinct genetic variants; Purple (PRP), Red (RED), Orange (ORG), Green (GRN), Lemon (LMN), Brown (BRN), Chocolate (CHO), Yellow (YLO), Magenta (MGT), Blue (BLU), Army green (AGN) and Navy blue (NBL) as described earlier by Gori et al. (2012) and Yang et al. (2016).
Table 1: Primers used during amplification and sequencing of HSP 90 gene in Nigerian zebu cattle

\begin{tabular}{llll}
\hline HSP 90 (5-3') & $\begin{array}{l}\text { Primer } \\
\text { length }\end{array}$ & $\begin{array}{l}\text { Target } \\
\text { region }\end{array}$ & $\begin{array}{l}\text { Amplicon } \\
\text { size }\end{array}$ \\
\hline F-GCGTCATCACGTGTCATCTT & 20 & Exon 3 & $450 \mathrm{bp}$ \\
R-CCTCCTTTGGGGTTCCAGT & 19 & & \\
\hline
\end{tabular}

Source: Kumar et al. (2015)

\section{Results}

Genetic Variants in HSP 90 Gene in Four Nigerian Zebu Cattle Breeds Revealed by qReal-Time PCR/High Resolution Melting (HRM)-Based Assays

We detected polymorphism at HSP 90 gene in the DNA samples from the four breeds of Nigerian zebu depicted by distinct SYBR green fluorescence dye and shown by HRM curve profiles (Fig. 3).

Polymorphisms were detected in DNA samples from at least each breed making a total of 110 in all DNA samples. These were grouped into 11 fluorescence groups representing distinct genetic variants (Table 2). On the basis of occurrence in breeds, we classify these as major or minor HSP 90 genetic variants in Nigerian zebu. Therefore, five variants namely PRP, RED, ORG, LMN and YLO were detected in at least three breeds and were regarded as major variants and the remaining (six) were detected in DNAs of one or two breeds and were classified as minor variants. Combined, the major variants constituted $70.1 \%$ of all variants while the minor variants comprised $29.1 \%$. We report the variants: GRN and NBL appeared once each detected in the RB and in SG breeds respectively. Number and percentage of individual variants are also shown in Table 2.

We rearranged the genetic variants to show the occurrence (distribution) of HSP 90 gene in each breed and we found that, seven (7) of them were in WF, eight (8) each in SG and RB and five (5) in AM (Table 3).

\section{Phylogenetic Relationship Among Four Nigerian Zebu Cattle Breeds Based on HSP 90 Gene Loci}

To study genetic relationship among the Nigerian zebu breeds, a Neighbour-Joining (NJ) dendrogram was constructed from the nucleotide sequences of HSP 90. This relationship is presented in Fig. 4. We have shown that all four zebu breeds have a shared clade and may have belonged to a common ancestry.

\section{Phylogenetic Relationship Among Four Nigerian Zebu Cattle Breeds and Selected Mammalian Species}

Further, a second NJ dendrogram was between the four cattle breeds and selected mammalian species including goat, sheep, yak, buffalo, camel, horse and other taurines. We also found a shared cluster and homology between these groups and suspected that the HSP 90 gene is strongly conserved among mammalian 
species. The NJ and the resulting relationships among the animals are shown in Fig. 5.

Table 2: Genetic variants for HSP 90 gene detected in DNA samples from four Nigerian zebu cattle breeds

\begin{tabular}{lclr}
\hline Genetic variants & Number & Breed & \% of total variants \\
\hline PRP & 26 & WF, AM, SG, RB & 23.6 \\
RED & 20 & WF, AM, SG, RB & 18.2 \\
ORG & 14 & WF, AM, SG, RB & 12.7 \\
GRN & 6 & RB & 5.5 \\
LMN & 10 & WF, SG, RB & 9.1 \\
BRN & 6 & AM, SG & 5.5 \\
CHO & 8 & WF, RB & 7.3 \\
YLO & 8 & AM, SG, RB & 7.3 \\
MGT & 6 & WF, RB & 5.5 \\
BLU & 4 & WF, SG & 3.6 \\
NBL & 2 & SG & 1.8 \\
Total & 110 & & 100.0
\end{tabular}

SYBR green dye fluorescence (PRP: Purple, RED: Red, ORG: Orange, GRN: Green, LMN: Lemon, BRN: Brown, CHO: Chocolate, YLO: Yellow, MGT: Magenta, BLU: Blue, AGN: Army green, NBL: Navy blue); Cattle breeds (WF: White Fulani, SG: Sokoto Gudali, RB: Red Bororo, AM-Ambala)

Table 3: Distribution of genetic variants of HSP 90 gene in four Nigerian zebu cattle

\begin{tabular}{lll} 
Breed & $H S P$ 90 gene variants & Number of variants per breed \\
\hline WF & PRP, RED, ORG, LMN, CHO, MGT, BLU & 7 \\
SG & PRP, RED, ORG, LMN, BRN, YLO, BLU, NBL & 8 \\
RB & PRP, RED, ORG, GRN, LMN, CHO, YLO, MGT & 8 \\
AM & PRP, RED, ORG, BRN, YLO & 5 \\
\hline
\end{tabular}

SYBR green dye fluorescence (PRP: Purple, RED: Red, ORG: Orange, GRN: Green, LMN: Lemon, BRN: Brown, CHO: Chocolate, YLO: Yellow, MGT: Magenta, BLU: Blue, AGN: Army green, NBL: Navy blue); Cattle breeds (WF: White Fulani, SG: Sokoto Gudali, RB: Red Bororo, AM-Ambala)
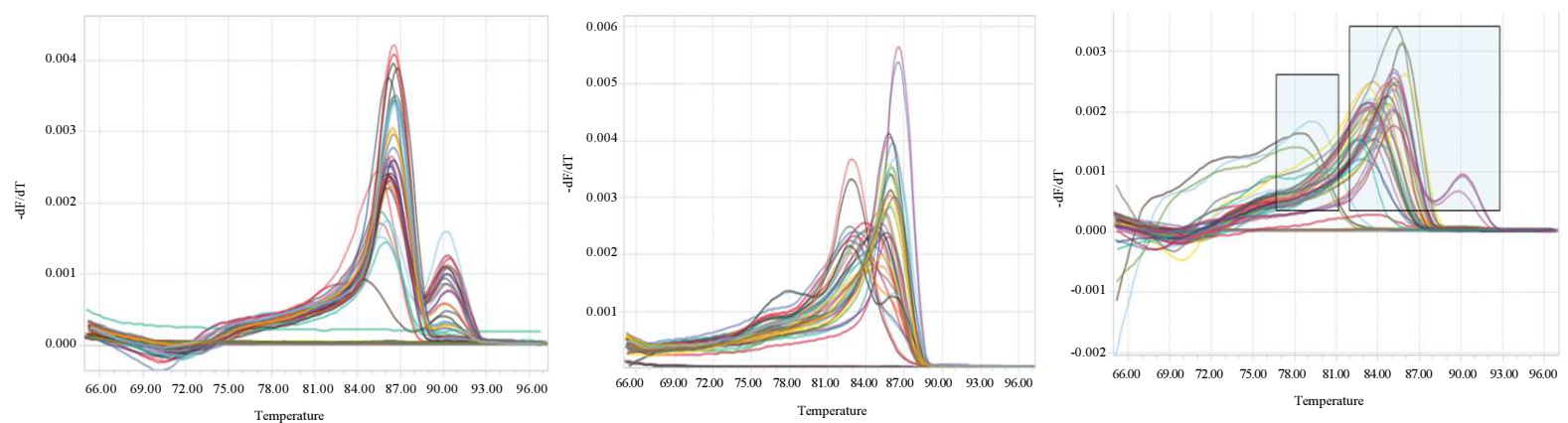

Temperature
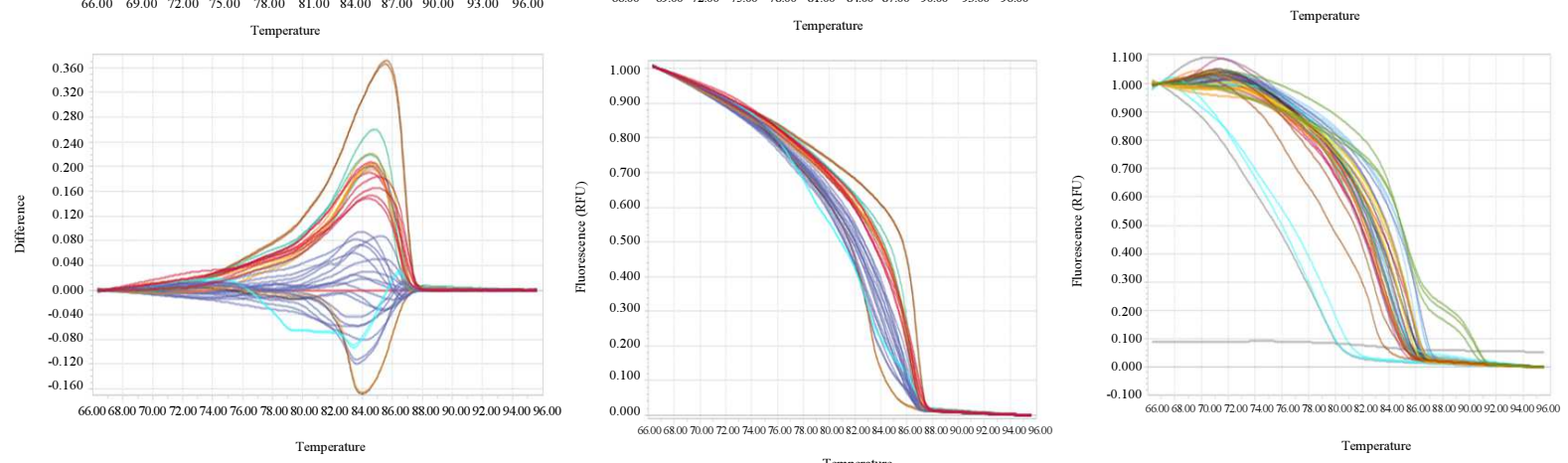

Fig. 3: High Resolution Melting (HRM) curve profile for HSP 90 gene depicting the presence of polymorphism in four Nigerian zebu breeds of cattle. Delta Tm Discrimination is $50 \%$ and curve shape discrimination is $50 \%$ 


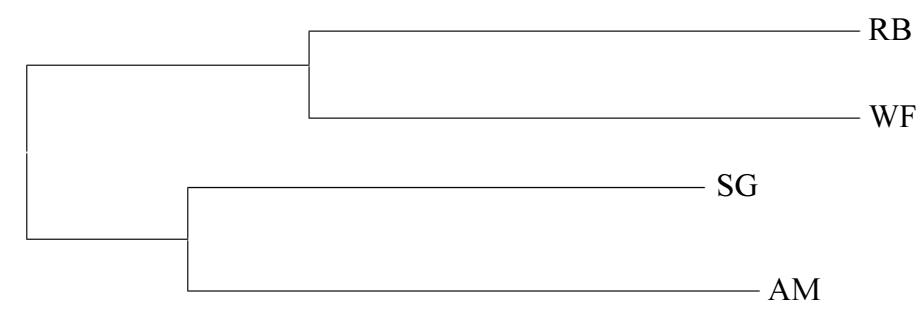

RB

WF

AM

0.2

Fig. 4: A Neighbour-Joining (NJ) tree showing genetic relationship among four Nigerian zebu breeds WF: White Fulani, SG: Sokoto Gudali, RB: Red Bororo, AM-Ambala

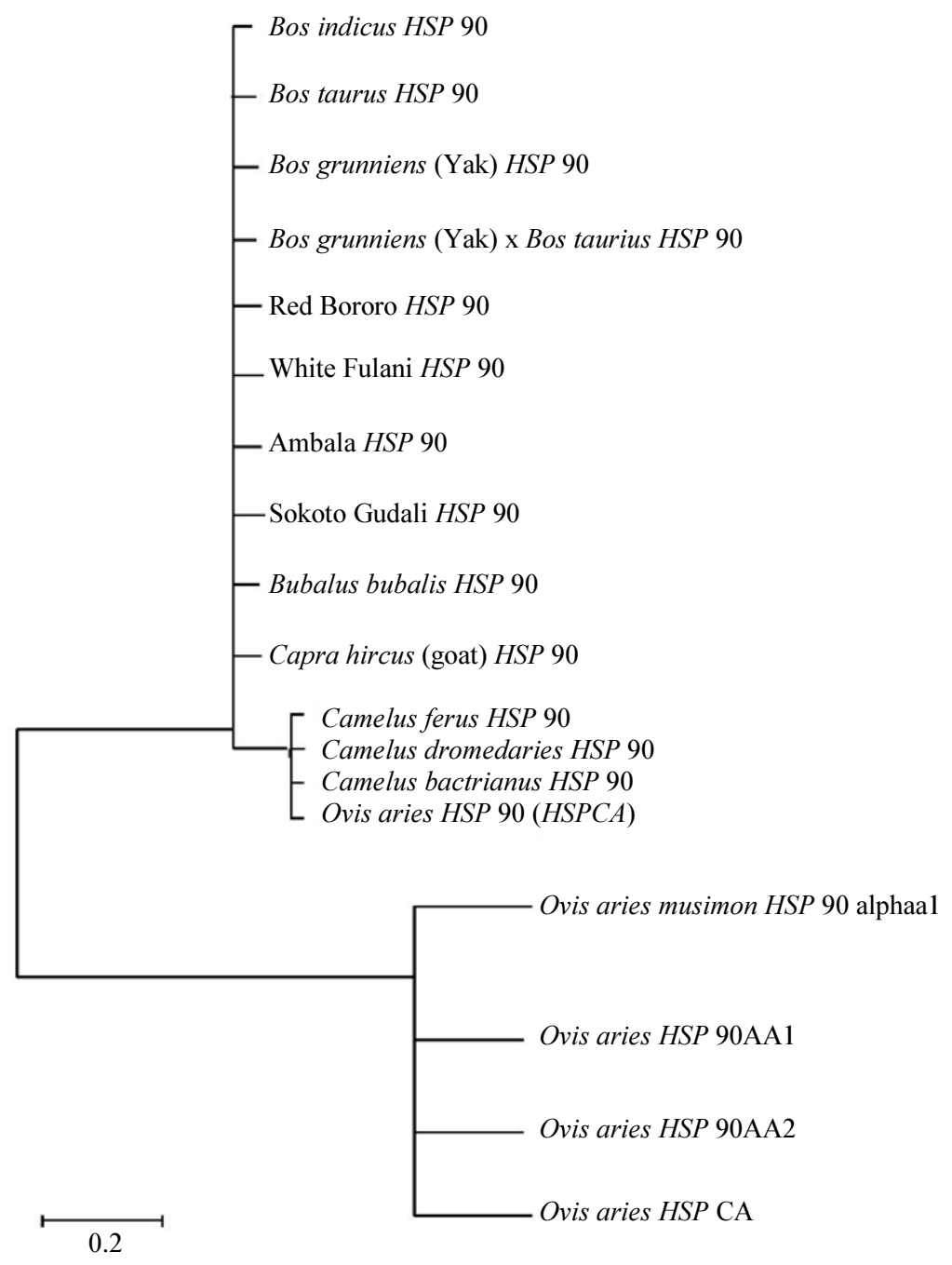

Fig. 5: A neighbour-joining (NJ) tree showing genetic relationship among four Nigerian zebu breeds and selected mammalian species. WF: White Fulani, SG: Sokoto Gudali, RB: Red Bororo, AM: Ambala 


\section{Discussion}

We employed qReal-Time PCR HRM-based assays to genotype and subsequently differentiate genetic variants in particular single nucleotide mutations (SNPs) or mutations in four Nigerian zebu cattle breeds. To the best of our knowledge, the genetic evaluation of these genes in these and other local cattle in Nigeria have not been reported. The PCR HRM-based assays are strongly informative (Bester et al., 2012; Gori et al., 2012; Yang et al., 2016) and have been used in the past few years to identify pathogens in humans and animals (Jeffery et al., 2007; Hewson et al., 2009; Wynyard et al., 2011), genotyping of drug-resistant bacteria isolates (Hoek et al., 2008; Castellanos et al., 2010) and detecting human genetic variants linked to cancer (Krypuy et al., 2006; 2007). We obtained 11 genetic variants in our animals, which are similar to the number reported for HSP 70 polymorphisms in Chinese Holstein cattle (Li et al., 2011). In China, Zhang et al. (2002a) detected polymorphism in HSP 70 gene in broiler chickens and Singh et al. (2006) reported polymorphism of the HSP 70 gene in humans. In pigs, Schwerin et al. (2001) and Schwerin et al. (2002) reported genetic diversity of HSP 70 gene. The genetic diversity of $H S P 90$ gene has been reported to confer a better thermo-tolerance, adaptability, survivability, longevity advantage and increased ability to respond to thermal stress in animals (Singh et al., 2006; Kapila et al., 2013; Sodhi et al., 2013b).

The differences among various genetic variants of HSP 90 gene as revealed by differential plot is an evidence of the presence of genetic diversity detected within different genetic groups HSP 90 gene (Bester, 2012; Gori et al., 2012; Yang et al., 2016). In the present study, the SG and RB breeds appeared to have more genetic variants at HSP 90 than WF and AM breeds showing a greater polymorphisms in the former's than the latter. The detected genetic variants of HSP 90 gene could be interrogated as veritable genetic resource for improvement programme of thermo-tolerance, adaptability and survivability advantage to cope with wide range of thermal stress and environmental variations especially in the hot humid tropics (Schwerin et al., 2002a; Kishore et al., 2013) as well as disease tolerance and drug resistance of animals under thermal stress (Zhang et al., 2002b; Aufricht, 2005; Singh et al., 2006).

The rooted evolutionary study based on Neighbourjoining dendrogram of $H S P 90$ sequences revealed a shared cluster among the four zebu breeds (WF, AM, SG and RB). Similarly, sequences of HSP 90 in four $B$. Indicus breeds and those of goat, sheep, yak, buffalo, camel, horse and other taurine demonstrated common clade architecture and therefore suggests evolution from a common ancestor (Gade et al., 2010). Other HSP genes or loci have been shown to be similar in mammalian species. For example, an earlier work of Gade et al. (2010) reported that HSP 70 gene of mammalian species showed high degree of relatedness. Pelham (1982) reported that HSP genes were highly conserved both in protein-coding sequence and in regulatory sequence with common homology. Gutierrez and Guerriero (1995) found that amino acid sequences of HSP70 gene were highly conserved among HSP sub-families. The degree of relatedness of nucleotide sequences of HSP 90 established within the four zebu breeds and those of selected mammalian species suggested that HSP 90 gene is conserved among wide range of animals (Pelham, 1982; Sodhi et al., 2013a; Kapila et al., 2013; Wang et al., 2015) and as such this gene can serve as a potential bio-marker for thermo-tolerance selection of animal under thermal assault during.

\section{Conclusion}

We detected 11 genetic variants of HSP 90 gene in four Nigerian zebu cattle detected by HRM based assays. These variants are detected in these animals for the first time and have been rarely reported in other animals including $B$. taurus. We tentatively associate these to the good thermo-tolerance traits in Nigerian indigenous including the four breeds evaluated in this study and we recommend further interrogation with respect to the thermo-regulatory functions of these novel genetic variants. Further, the genetic variants in Nigerian zebu breeds could be used as veritable genetic resource for selection and breeding programmes with regard to thermo-tolerance ability, adaptability and survivability to cope with wide range of thermal stress and environmental variations especially in the hot humid tropics. Moreover, the shared homology of HSP 90 in Nigerian zebu breeds is an implication of high nucleotide sequences similarity which is indicative of common ancestral lineage. Similarly, shared cluster architecture between HSP 90 in B. indicus and the selected mammalian species is suggestive of shared evolution and ancestry. These results may also indicate that the HSP 90 gene is conserved among wide range of animals and as such it can be used as bio-marker for marker assisted selection for thermo-tolerance in wide range of livestock animals under thermal assault. We recommend the qReal-Time PCR HRM-based technologies for evaluation of polymorphism in various genes in zebu cattle breeds.

\section{Acknowledgement}

We thank the management of slaughter houses in Nigeria for giving us permission to sample from the animals in their custodian. 


\section{Funding Information}

This study was funded by The Government of India in a form of visiting scholarship the Research Fellowship for Developing Countries Scientists (RFDCS) to Gbolabo Onasanya and CV Raman International Fellowship for African Researchers for George Msalya. Both programmes are administered by the Department of Science and Technology (DST) and Ministry of External Affairs (MEA) of the Government of India, New Delhi.

\section{Authors' Contributions}

Gbolabo Onasanya: Conceptualized and designed the experiments, performed the experiments, carried out the analysis, did the statistical analysis, drafted the manuscript, provide editorial suggestions, revisions, read and approve the final draft.

George Msalya: Performed the experiments, carried out the analysis, did the statistical analysis, structured scientific content, provide editorial suggestions, revisions, read and approve the final draft.

Aranganoor Thiruvenkadan: Conceptualized and designed the experiments, contributed reagents.

Chirukandoth Sreekumar: Conceptualized and designed the experiments, contributed reagents, performed the experiments, carried out the analysis, provide editorial suggestions, revisions, read and approve the final draft.

Krishnaswamy Tirumurugaan and Sanni Muyideen: Contributed reagents, provide editorial suggestions, revisions, read and approve the final draft.

John Decampos, Ayotunde Amusan and Moses Okpeku: Provided editorial suggestions, revisions, read and approve the final draft.

Olajide Olowofeso, Adeboye Fafiolu and Christian Ikeobi: Conceptualized and design the experiments, provide editorial suggestions, revisions, read and approve the final draft.

Abdulmojeed Yakubu: Structured scientific content, provide editorial suggestions, revisions, read and approve the final draft.

\section{Ethics}

The authors declare that the sampling, methodology and conduct of this study did not ruin animals and humans welfare anywhere.

\section{References}

Aufricht, C., 2005. Heat-shock protein 70: Molecular supertool. Pediatr. Nephrol., 20: 707-713.

DOI: $10.1007 / \mathrm{s} 00467-004-1812-6$
Alphonsus, C., G.N. Akpa, P.P. Barje, H.I. Finangwai and B.D. Adamu, 2012. Comparative evaluation of linear udder and body conformation traits of Bunaji and Friesian x Bunaji cows. World J. Life Sci. Med. Res., 2: 134-140.

Babayemi, O.J., O.A. Abu and A. Opakunbi, 2014. Integrated Animal Husbandry for Schools and Colleges. 1st Edn., Positive Press Ibadan, Nigeria.

Basiricò, L., P. Morera, V. Primi, N. Lacetera and A. Nardone et al., 2011. Cellular thermotolerance is associated with heat shock protein 70.1 genetic polymorphisms in Holstein lactating cows. Cell Stress Chaperones, 16: 441-448.

DOI: $10.1007 / \mathrm{s} 12192-011-0257-7$

Bester, R., A.E.C. Jooste, H.J. Maree and J.T. Burger, 2012. Real-time RT-PCR high-resolution melting curve analysis and multiplex RT-PCR to detect and differentiate grapevine leafroll-associated associated virus 3 variant groups I, II, III and VI. Virol. J., 9: 219-219. DOI: $10.1186 / 1743-422 X-9-219$

Blench, R.M., A. De Jode, E. Gherzi and C. Di Domenico, 1998. Keteku and Ndama Crossbred Cattle in Nigeria: History, Distribution and Productivity. In: Des Taurins au Cameroun et Nigeria, Seignobos, C. and E. Thys Paris (Eds.), ORSTOM/IEMVT, Maisons-Alfort,

ISSN-10: 1278-348X, pp: 293-310.

Castellanos, E., A. Aranaz and J. De Buck, 2010. PCR amplification and highresolution melting curve analysis as a rapid diagnostic method for genotyping members of the Mycobacterium aviumintracellulare complex. Clin. Microbiol. Infect., 16: 1658-1662.

DOI: $10.1111 /$ j.1469-0691.2010.03198.x

Collier, R.J., J.L. Collier, R.P. Rhoads and L.H. Baumgard, 2008. Invited review: Genes involved in the bovine heat stress response. J. Dairy Sci., 91: 445-454. DOI: $10.3168 / \mathrm{jds} .2007-0540$

Gade, N., R.K. Mahapatra, A. Sonawane, V.K. Singh and R. Doreswamy et al., 2010. Molecular characterization of heat shock protein 70-1 gene of goat (Capra hircus). Mol. Biol. Int., 7: 1-7. DOI: $10.4061 / 2010 / 108429$

Gori, A., M. Cerboneschi and S. Tegli, 2012. Highresolution melting analysis as a powerful tool to discriminate and genotype Pseudomonas savastanoi pathovars and strains. PLoS ONE, 7: e30199-e30199. DOI: 10.1371 journal.pone.0030199

Gutierrez, J.A. and V. Guerriero Jr, 1995. Chemical modifications of a recombinant bovine stressinducible $70 \mathrm{kDa}$ heat shock protein (Hsp70) mimics Hsp70 isoforms from tissues. Biochem. J., 305: 197-203. DOI: 10.1042/bj3050197 
Hansen, P.J., 2004. Physiological and cellular adaptations of Zebu cattle to thermal stress. Anim. Reprod. Sci., 82-83: 349-360.

DOI: $10.1016 /$ j.anireprosci.2004.04.011

Hewson, K., A.H. Noormohammadi, J.M. Devlin, K. Mardani and J. Ignjatovic, 2009. Rapid detection and non-subjective characterisation of infectious bronchitis virus isolates using high-resolution melt curve analysis and a mathematical model. Arch. Virol., 154: 649-660.

DOI: $10.1007 / \mathrm{s} 00705-009-0357-1$

Hoek, K.G.P., N.C. Gey van Pittius, H. MoolmanSmook, K. Carelse-Tofa and A. Jordaan, 2008. Fluorometric assay for testing rifampin susceptibility of Mycobacterium tuberculosis complex. J. Clin. Microbiol., 46: 1369-1373. DOI: 10.1128/JCM.02343-07

Jeffery, N., R.B. Gasser, P.A. Steer and A.H. Noormohammadi, 2007. Classification of Mycoplasma synoviae strains using single-strand conformation polymorphism and high resolution melting- curve analysis of the vlhA gene singlecopy region. Microbiology, 153: 2679-2688.

DOI: $10.1099 /$ mic. $0.2006 / 005140-0$

Kapila, N., A. Kishore, M. Sodhi, A. Sharma and B. Mohanty et al., 2013. Temporal changes in mRNA expression of heat shock protein genes in mammary epithelial cells of riverine buffalo in response to heat stress in vitro. Int. J. Anim. Biotechnol., 3: 5-9.

Katie, T. and F. Alistair, 1986. The complete book of raising livestock and poultry-A small holder's guide. University Services Ltd., Yaba Lagos, Nigeria.

Kishore, A., M. Sodhi, K. Khate, N. Kapila and P. Kumari et al., 2013. Selection of stable reference genes in heat stressed peripheral blood mononuclear cells of tropically adapted Indian cattle and buffaloes. Mol. Cell. Probes, 3-4: 140-144. DOI: $10.1016 /$ j.mcp.2013.02.003

Kubkomawa, H.I., 2017. Indigenous breeds of cattle, their productivity, economic and cultural values in sub-Saharan Africa. Int. J. Res. Studies Agric. Sci., 3: 27-43. DOI: 10.20431/2454-6224.0301004

Kumar, R., I.D. Gupta, A. Verma, N. Verma and M.R. Vineeth, 2015. Genetic polymorphisms within exon 3 of heat shock protein 90AA1 gene and its association with heat tolerance traits in Sahiwal cows. Vet. World, 8: 932-936.

DOI: 10.14202/vetworld.2015.932-936

Krypuy, M., A.A. Ahmed, D. Etemadmoghadam, S.J. Hyland and A. De Fazio, 2007. High resolution melting for mutation scanning of TP53 exons 5-8. BMC Cancer, 7: 168-168.

DOI: $10.1186 / 1471-2407-7-168$
Krypuy, M., G.M. Newnham, D.M. Thomas, M. Conron and A. Dobrovic, 2006. High resolution melting analysis for the rapid and sensitive detection of mutations in clinical samples: KRAS codon 12 and 13 mutations in non-small cell lung cancer. BMC Cancer, 6: 295-295. DOI: 10.1186/1471-2407-6-295

Lee, W.C., H.C. Wen, C.P. Chang, M.Y. Chen and M.T. Lin, 2006. Heat shock protein 72 overexpression protects against hyperthermia, circulatory shock and cerebral ischemia during heat stroke. J. Applied Physiol., 100: 2073-2082.

DOI: 10.1152/japplphysiol.01433.2005

Li, L., Y. Yan, X. Haoxiang, Q. Tao and W. Baoxi, 2011. Selection of reference genes for gene expression studies in ultraviolet B-irradiated human skin fibroblasts using quantitative real-time PCR. BMC Molecular Biol., 12: 8-8. DOI: $10.1186 / 1471-2199-12-8$

Meghen, C., D.E. MacHugh, B. Sauveroche, G. Kana and D.G. Bradley, 1999. Characterization of the Kuri Cattle of Lake Chad using Molecular Genetic Techniques. In: The Origin and Development of African Livestock, Blench, R.M. and K.C. MacDonald (Eds.), University College Press, London, pp: 28-86.

NNLRS, 1999. Nigerian national livestock resource survey.

Onasanya, G.O., A.K. Thiruvenkadan, C. Sreekumar, M. Okpeku and G.K. Tirumurugaan et al., 2019. Molecular characterization of hsp 70 gene using single nucleotide polymorphism in nigerian breeds of zebu cattle. FUW Trends Sci. Technol. J., 4: 714-720.

Pagot, J., 1992. Animal production in the tropics and subtropics. The MacMillan Press Ltd, London and Basingstoke. ISBN-10: 0333538188, pp: 358.

Pelham, H.R.B., 1982. A regulatory upstream promoter element in the Drosophila HSP 70 heat-shock gene. Cell, 30: 517-528.

DOI: 10.1016/0092-8674(82)90249-5

Schwerin, M., S. Maak, A. Hagendorf, G. Lengerken and H.M. Seyfert, 2002. A 3'UTR variant of the inducible porcine HSP70.2 gene affects mRNA stability. Biochem. Biophys. Acta, 1578: 90-94. DOI: 10.1016/s0167-4781(02)00448-7

Schwerin, M., S. Maak, C. Kalbe and R. Fuerbass, 2001. Functional promoter variants of highly conserved inducible hsp70 genes significantly affect stress response. Biochem. Biophys. Acta, 1522: 108-111. DOI: 10.1016/s0167-4781(01)00313-X

Singh, R., S. Kolvraa, P. Bross, U.B. Jensen and N. Gregersen et al., 2006. Reduced heat shock response in human mononuclear cells during aging and its association with polymorphisms in HSP70 genes. Cell Stress Chaperones, 11: 208-215.

DOI: $10.1379 /$ csc-184r.1 
Sodhi, M., A. Kishore, K. Khate, N. Kapila and B.P. Mishra et al., 2013a. Evaluating suitable internal control genes for transcriptional studies in heatstressed mammary explants of buffaloes. J. Anim. Breed. Genet., 130: 106-117. DOI: 10.1111/j.1439-0388.2012.01004.x

Sodhi, M., M. Mukesh, A. Kishore, B.P. Mishra and R.S. Kataria et al., 2013b. Novel polymorphisms in UTR and coding region of inducible heat shock protein 70.1 gene in tropically adapted Indian Zebu cattle (Bos indicus) and riverine buffalo (Bubalus bubalis). Gene, 527: 606-615. DOI: $10.1016 /$ j.gene.2013.05.078

Tamura, K., D. Peterson, N. Peterson, G. Stecher and M. Nei et al., 2011. MEGA5: Molecular evolutionary genetics analysis using maximum likelihood, evolutionary distance and maximum parsimony methods. Mol. Biol. Evol., 28: 2731-2739.

DOI: $10.1093 / \mathrm{molbev} / \mathrm{msr} 121$

Wang, L., S. Yang, L. Han, K. Zhao and L. Ye, 2015. Expression profile of Two HSP70 chaperone proteins in response to extreme thermal acclimation in Xestia c-nigrum (Lepidoptera: Noctuidae). Fla. Entomol., 98: 506-515. DOI: 10.1653/024.098.0218

West, J.W., 2003. Effects of heat stress in dairy cattle. J. Dairy Sci., 86: 2131-2144.

DOI: $10.3168 /$ jds.S0022-0302(03)73803-X
Williamson, G. and W.J.A. Payne, 1990. An introduction to animal husbandry in the tropics. Longman Group, London. UK.

Wynyard, S., O. Garkavenko and R. Elliot, 2011. Multiplex high resolution melting assay for estimation of Porcine Endogenous Retrovirus (PERV) relative gene dosage in pigs and detection of PERV infection in xenograft recipients. J. Virol. Methods, 175: 95-100.

DOI: $10.1016 /$ j.jviromet.2011.04.026

Yang, J., B. Kemps-Mols, M. Spruyt-Gerritse, J. Anholts and F. Claas et al., 2016. The source of syber green master mix determines outcome of nucleic acid amplification reactions. BMC Res. Notes, 9: 292-292. DOI: $10.1186 / \mathrm{s} 13104-016-2093-4$

Zhang, X., H. Du and J. Li, 2002a. Single nucleotide polymorphism of chicken Heat Shock Protein (HSP70) gene. Proceedings of the 7th World Congress on Genetics Applied to Livestock Production, Aug. 19-23, Montpellier, France.

Zhang, Y., L. Huang, J. Zhang, D. Moskophidis and N.F. Mivechi, 2002b. Targeted disruption of hsf1 leads to lack of thermo-tolerance and defines tissue specific regulation for stress-inducible HSP molecular chaperones. J. Cell Biochem., 86: 376-393.

DOI: $10.1002 /$ jcb. 10232 